\title{
Membidik Potensi Ekonomi Syariah di Lembaga Pendidikan Pondok Pesantren
}

\author{
Muhammad Zuhirsyan \\ Politeknik Negeri Medan \\ email: zuhirsyan12@gmail.com
}

\begin{abstract}
This study aims to explore Islamic economic empowerment in Islamic boarding schools. Various resources in Islamic boarding schools can be empowered as facilities in implementing and developing Islamic economics. This research method uses a phenomenological qualitative approach that is analytical and inductive descriptive. The object of this study uses several modern boarding schools in Medan, Langkat, Deli Serdang and Serdang Bedagai, North Sumatra. The results show that Islamic economic empowerment can be in the form of application in Islamic boarding schools that can be classified in several ways, including sharia economic principles education, contract and sharia economic cooperation, pesantren accounting and sharia accommodation, culinary and halal tourism. While in the form of sharia economic development, Islamic boarding schools as an institution known for its independence can make Islamic boarding schools as a sharia economic assessment laboratory, form a sharia business forum, become an Islamic economics center and inspire sharia-based economic development. This study uses a phenomenological qualitative approach that is descriptive analytical and inductive in nature by digging data to find the basic things of phenomena, reality and experience.
\end{abstract}

Keywords: Sharia Economy; Empowerment; Islamic Boarding Schools

\begin{abstract}
Abstrak: Penelitian ini bertujuan untuk menggali pemberdayaan ekonomi syariah di dalam lembaga pendidikan pesantren. Berbagai sumber daya yang ada di dalam pesantren bisa diberdayakan sebagai fasilitas dalam penerapan dan pengembangan ekonomi syariah. Metode penelitian ini menggunakan pendekatan kualitatif fenomologi yang bersifat deskriptif analitis dan induktif. Objek penelitian ini menggunakan beberapa pesantren modern yang berada di Kota Medan, Langkat, Deli Serdang dan Serdang Bedagai, Sumatera Utara. Hasil penelitian menunjukkan Pemberdayaan ekonomi Islam ini bisa dalam bentuk penerapan di dalam pondok pesantren yang dapat diklasifikasi dalam beberapa hal, di antaranya pendidikan prinsip ekonomi syariah, akad dan kerjasama ekonomi syariah, akuntansi pesantren serta penginapan syariah, kuliner dan wisata halal. Sementara dalam bentuk pengembangan ekonomi syariah, pesantren sebagai lembaga yang dikenal dengan kemandiriannya bisa menjadikan pesantren sebagai laboratorium pengkajian ekonomi syariah, membentuk forum bisnis syariah, menjadi islamic ekonomy centre dan inspirator pengembangan ekonomi berbasis syariah. Penelitian ini menggunakan pendekatan kualitatif fenomenologi yang bersifat deskriptif analitis dan induktif dengan menggali data untuk menemukan hal-hal mendasar dari fenomena, realitas maupun pengalaman.
\end{abstract}

Kata Kunci: Ekonomi Syariah; Pemberdayaan; Pesantren

Economica: Jurnal Ekonomi Islam - Volume 9, Nomor 2 (2018) 


\section{Pendahuluan}

Pesantren di Indonesia merupakan lembaga yang telah menjadi bagian yang tidak terpisahkan dalam masyarakat Muslim Indonesia. Sejarah mencatat peran pengembangan agama kerap diperankan oleh lembaga pesantren secara berkesinambungan dan telah banyak memberikan kontribusi dalam kehidupan masyarakat Islam (Wibowo 2016). Berbagai sumber daya yang ada di dalam pesantren adalah modal sosial yang besar dalam kegiatan memainkan perannya sebagai lembaga yang bertugas dan bertanggung jawab untuk melahirkan individu-individu islami yang mampu menjawab berbagai tantangan zaman.

Kemandirian yang diterapkan pesantren bisa menjadi bekal dalam menghidupkan jiwa-jiwa yang tangguh dalam menjawab berbagai tantangan zaman. Di sisi lain, ekonomi syariah yang semakin berkembang di Indonesia seyogyanya benar-benar "hidup" di dalam diri setiap muslim sebagai pengamalan ajaran agama dan untuk membangkitkan kejayaan Islam sebagaimana yang telah dibuktikan di masa lampau. Pesantren sebagai lembaga pendidikan Islam dianggap benar-benar mampu dalam menerapkan sistem ini untuk kemudian melahirkan ilmuan-ilmuan syariah yang berkompeten dan mampu untuk menyebarluaskan semua ajara agama termasuk ekonomi syariah.

Ironis rasanya jika lembaga pendidikan seperti pesantren dan para pendidik di dalamnya malah bekerjasama dengan lembaga keuangan konvensional dalam menjalankan kegiatan ekonominya, padahal potensi pengembangan ekonomi syariah sangat besar dan bisa dijalankan dengan baik dan maksimal. Masih banyak pesantren maupun para guru di dalamnya yang masih berinteraksi dengan perbankan konvensional, lembaga leasing dan pembiayaan non-syariah serta lainnya. Demikian juga akad-akad bisnis syariah belum maksimal diterapkan dalam dunia pendidikan pesantren seperti jual-beli, sewa-menyewa, simpan-pinjam dan lain sebagainya. 
Idealnya, pesantren bisa berupaya mewujudkan praktik-praktik ekonomi yang berbasis syariah dalam berbagai kegiatan ekonominya. Praktik ekonomi berbasis syariah ini belum secara maksimal digali dan diaplikasikan oleh lembaga pendidikan pesantren, mengingat berbagai keterbatasan yang masih dimiliki termasuk SDM dan materi, namun paling tidak secara perlahan pratik tersebut dapat bisa dijalankan. Sebagai lembaga pendidikan Islam, pesantren layak dan sesuai untuk dijadikan tempat penerapan bahkan pengkajian ekonomi syariah. Berbagai akad syariah yang bisa diterapkan di dalam pesantren, baik secara internal maupun eksternal. Ilmu-ilmu syariah yang dipelajari di dalam pesantren bisa dijadikan legal standing dalam penerapan dan pengembangan ekonomi syariah, untuk kemudian menyebarluaskannya ke masyarakat luas.

Dalam tulisan ini, akan digali berbagai potensi ekonomi syariah yang dapat diberdayakan di dalam kehidupan pesantren melalui pengamatan yang komprehensif terhadap realitas yang ada di berbagai pesantren, baik itu pemberdayaan terhadap yang potensi belum tergali maupun pengembangan potensi pada beberapa bentuk penerapan ekonomi syariah yang bisa dijalankan.

\section{Metode Penelitian}

Penelitian ini menggunakan pendekatan kualitatif fenomenologi yang bersifat deskriptif analitis dan induktif. Penelitian ini berusaha menggali data untuk menemukan hal-hal mendasar dari fenomena, realitas maupun pengalaman. Penelitian ini menggunakan studi dokumenter dan telaah teoriteori yang digunakan untuk menjelaskan dan menyimpulkan permasalahan yang diangkat dalam penelitian ini. Adapun pesantren yang menjadi objek penelitian adalah beberapa pesantren modren yang terdapat di Kota Medan, Langkat, Deli Serdang, dan Serdang Bedagai yang berada di wilayah Provinsi Sumatera Utara.

Economica: Jurnal Ekonomi Islam - Volume 9, Nomor 2 (2018) 


\section{Pondok Pesantren dalam Realitas Keilmuan dan Ekonomi}

Kata Pondok berasal dari kata funduq yang berarti hotel atau asrama. Sedangkan dalam bahasa Indonesia mempunyai banyak arti, di antaranya adalah madrasah tempat belajar agama Islam (Hafidhoh 2016). Pesantren berasal dari kata santri yang dapat diartikan tempat santri. Kata santri berasal dari kata Cantrik (bahasa sansakerta, atau mungkin jawa) yang berarti orang yang selalu mengikuti guru, yang kemudian dikembangkan oleh PErguruan Taman Siswa dalam sistem asrama yang disebut Pawiyatan. Istilah santri juga ada dalam bahasa Tamil yang berarti guru mengaji (Fatah, Taufik, dan Bisri 2005). Adapun C.C. Berg berpendapat bahwa istilah tersebut berasal dari istilah shastri yang dalam bahasa India berarti orang yang tahu buku-buku suci agama Hindu atau seorang sarjana ahli kitab suci agama Hindu. Kata shastri berasal dari shastra yang berarti buku suci, bukubuku agama atau buku-buku tentang ilmu Pengetahuan (Daulay 2014). Terkadang dianggap sebagai gabungan kata saint (manusia baik) dengan suku kata tra (suka menolong) sehingga kata ini berarti tempat pendidikan manusia baik-baik (Fatah, Taufik, dan Bisri 2005).

Menurut Rahardjo (1985), pesantren adalah sebuah lembaga pendidikan dan penyiaran agama Islam. Itulah identitas pesantren pada awal perkembangannya. Sekarang setelah terjadi banyak perubahan dalam masyarakat, sebagai akibat dari pengaruhnya, definisi ini tidak lagi memadai, walaupun pada intinya pesantren tetap berada pada fungsi aslinya, yang selalu dipelihara di tengah arus perubahan yang deras.

Sebagaimana yang dikutip Fatah, Taufik, dan Bisri (2005), secara definitif Zarkasyi mengartikan pesantren sebagai lembaga pendidikan Islam dengan sistem asrama atau pondok, dimana kyai sebagai figure sentralnya, meskid sebagai pusat kegiatan yang menjiwainya dan pengajaran agama Islam dibawah bimbingan kyai yang diikuti santri sebagai kegiatan utamanya. Secara singkat pesantren bisa juga dikatakan sebagai 
laboratorium kehidupan, tempat para santri belajar hidup dan bermasyarakat dalam berbagai segi dan aspeknya.

Definisi ini menunjukkan ada peran pesantren sebagai miniatur kehidupan bermasyarakat di dalamnya, dimana para santri yang menuntut ilmu di dalamnya dipersiapkan untuk menghadapi problematika hidup bermuamalah di masyarakat dengan menunjung tinggi pilar-pilar religiusitas.

Seiring dengan perjalanannya, pesantren dapat dikategorisasi menjadi beberapa pola elemen dasarnya. Pola I adalah pesantren yang terdiri dari hanya masjid dan rumah kyai. Pesantren yang seperti ini masih bersifat sederhana. Pola II adalah pesantren yang terdiri dari masjid, rumah kyai dan pondok. Dalam pola ini pesantren telah memiliki pondok atau asrama yang disediakan bagi para santri yang dari dari daerah. Pola III pesantren yang terdiri dan masjid, rumah kyai, pondok, dan madrasah. Pesantren yang dalam pola ini memakai sistem klasikal, dimana santri yang mondok mendapatkan pendidikan di madrasah. Pola IV terdiri dari masjid, rumah kyai, pondok, madrasah, dan tempat keterampilan. Dalam pola ini disampng memiliki madrasah juga memiliki tempat-tempat keterampilan. Kemudian, pola $\mathrm{V}$ adalah pesantren yang terdiri dari masjid, rumah kyai, pondok, madrasah, tempat keterampilan, universitas, gedung pertemuan, tempat olah raga, dan sekolah umum. Dalam pola ini pesantren yang sudah berkembang dan bisa digolongkan pesantren mandiri (Daulay 2014).

Dhofier dalam Marlina (2014) mengemukakan, bahwa setidaknya terdapat lima unsur yang sudah menjadi keniscayaan untuk kemudian disebut sebagai pesantren. Kelima unsur tersebut adalah pondok (tempat tinggal), masjid, santri, kyai dan pengajaran kitab Islam klasik. Selanjutnya, santri dapat dibuat dua kategori, yaitu santri dengan sebutan "santri kalong" dan "santri mukim." Santri kalong merupakan bagian santri yang tidak menetap dalam pondok tetapi pulang ke rumah masing-masing sesudah selesai mengikuti suatu pelajaran di pesantren. Santri kalong biasanya 
berasal dari daerah-daerah sekitar pesantren sehingga diizinkan tidak tinggal di pondok. Adapun yang dimaksud dengan "santri mukim" ialah santri yang ditetapkan untuk menetap di pondok pesantren karena berasal dari daerah yang jauh. Pada masa lalu, kesempatan untuk pergi dan menetap di sebuah pesantren yang jauh merupakan suatu keistimewaan dan kebanggaan bagi santri. Dengan tinggal di ponpes santri disiapkan untuk memiliki cita-cita, mampu mandiri, berani dan siap menghadapi sendiri tantangan yang akan dialaminya di pesantren (Zuhriy 2011).

Menurut Haedari (2006), selain sebagai media pendidikan bagi para santri, ternyata pesantren memiliki fungsi yang sangat signifikan yaitu sebagai basis dakwah sekaligus media control terhadap prilaku budaya yang berkembang di masyarakat sekitar. Peran pesantren sebagai media pengawal umat menuju maslahat terlah berlangsung secara turun menurun. Dalam kerangka pembangunan material, fisik, ekonomi serta keamanan masyarakat kyai (sebagai salah satu unsurnya) memiliki andil yang tak kalah pentingnya.

Dalam pengembangan SDM ada 6 kekuatan yang dapat dibangun sekaligus menjadi tanggungjawab pesantren sebagai lembaga pendidikan. Keenam kekuatan itu adalah: 1. Kekuatan Iman, 2. Kekuatan Ilmu, 3. Kekuatan Ekonomi, 4. Kekuatan Semangat juang, dan 5. Kekuatan Kesetiakawanan (Hasan 2004).

Kekuatan ekonomi inilah yang salah satunya sangat layak dikembangkan di dunia pesantren dengan tidak mengenyampingkan beberapa kekuatan lainnya. Pengelolaan pesantren yang bisanyanya dilakukan dengan musyawarah mencapai mufakat sangat mendukung program penguatan ekonomi dapat diwujudkan. Dengan persatuan dan pengelolaan yang baik, maka pemberdayaan ekonomi pesantren dalam dimaksimalkan dengan baik. Sistem ekonomi pesantren merupakan tata cara pesantren menggali berbagai potensi dan mengelola sendi-sendi perekonomiannya yang bertujuan untuk bisa mandiri dalam memenuhi 
berbagai kebutuhannya di bidang ekonomi, baik bagi para penghuni pesantren itu maupun kebutuhan masyarakat sekitar dan masyarakat umum secara luas.

Potensi swadaya dan kemandirian pesantren yang cukup bagus (tidak melulu menunggu bantuan pemerintah) akan lebih bagus lagi jika memiliki sumber dana yang pasti yang digali dari dalam pesantren. Seperti yang kita ketahui pesantren memiliki santri, wali santri dan para ustadz serta warga sekitar, setiap komponen tadi masing-masing memiliki daya beli yang tinggi, untuk itu pesantren bisa memanfaatkan suasana tersebut dengan membuat warung yang bisa dijadikan masukan untuk pesantren. Selain warung, pesantren juga bisa mengorganisir makan santri, jika ada sisanya bisa dijadikan infaq untuk keperluan pesantren. Hal ini biasa dilakukan di pesantren, dan ada juga pesantren yang mengembangkan pertanian sebagai sumber masukan pesantren semuanya disesuaikan dengan situasai dan kondisi pesantren itu berada (Fatah, Taufik, dan Bisri 2005).

Biasanya para pengelola pesantren berjiwa wirausaha yang tinggi sesuai dengan sunnah nabi. Jadi, mereka berusaha menghidupi dirinya baik dengan jalan berdagang; pagi hari setelah mengajar subuh pergi ke pasar untuk berdagang, setelah dzuhur mengajar lagi. Ada juga dengan cara menerima panggilan ceramah. Pada tahun 1970-an pola pencarian nafkah kyai adalah dengan jalan berjualan kitab, obat dan minyak wangi keliling kampung dengan bersepeda dan ada juga yang menjadi PKL di pasar menjual pakaian jadi. Bagi pesantren-pesantren besar biasanya perekonomian pengelolaannya dengan cara kesejahteraan bulanan (gaji). Namun itupun biasanya dibahasakan dengan pengganti uang sabun serta untuk membantu kesejahteraan agar bisa beribadah mengajar, bukan gaji imbalan atau honor. Jadi, walau prakteknya gajian juga ditanamkan nilai religi dalam penyampaiannya sehingga para pengelola tidak "bekerja" sebegai pengajar hingga berhak mendapat upah, tapi beribadah mengajar para santri Lillahi sedang kesejahteraan yang diterima adalah rizki dari Allah 
(Fatah, Taufik, dan Bisri 2005). Ada juga lembaga pendidikan pesantren yang menggunakan istilah Ihsan atau Ikram sebagai ungkapan gaji yang pada intinya ingin mengedepankan mengajar dalam sisi ibadah dan pengabdian dibanding menganggapnya sebagai suatu pekerjaan untuk menghasilkan pendapatan. Untuk mendapatkan kesejahteraan, para pengelola juga dapat menjadi pemberi layanan dapur, dimana para pengasuh dan keluarganya diberikan kesempatan menyediakan makanan sekelompok santri. Selain itu ada juga yang memproduksi atau distribusi makanan/jajajan para santri, menyediakan bahan makanan pokok dan lainnya di pesantren.

Semangat "mengajar" kalangan pesantren bukan karena upah atau gaji, tapi karena semangat menyebarluaskan ilmu pengetahuan dan tanggungjawab dakwah Islamiyah, potensi inilah yang kemudian mampu mentransfer tidak saja pengetahuan tapi juga praktek ubudiyah amaliyah serta jiwa wirausaha kepada para santrinya dan membekas di tubuh santri, by doing not by mouth, dengan contoh dan keteladanan bukan hanya bicara (Fatah, Taufik, dan Bisri 2005).

Di dalam pesantren para pengelola mengajarkan melalui praktik yang mereka lakukan sendiri bahwa dalam membesarkan pesantren dan meraih kesejahteraan tidak perlu ada rasa malu. Selama yang dilakukan adalah benar dan sesuai garis syariah, maka pekerjaan apapun layak dikerjakan dengan maksimal. Para guru atau ustadz tidak jarang memperlihatkan di depan santrinya bagaimana dia ikut serta membersihkan pesantren dan melakukan kegiatan bisnis untuk memenuhi kesejahteraan keluarganya dengan berjualan, membawa dagangan yang secara tidak langsung adalah pendidikan kepada para santri.

Dalam realitas ekonomi pesantren, berbagai potensi ekonomi banyak yang belum tergali dengan baik. Tidak banyak pesantren yang menjalankan kegiatan usaha intra pesantren untuk meningkatkan kesejahteraan lembaga dan juga para pengasuh yang ada di dalamnya. Disamping itu, ada pesantren yang belum memberdayakan sendiri berbagai potensi ini dan 
menyerahkannya kepada pihak luar untuk mengambil alih pengelolaan beberapa bidang ekonomi yang bisa diberdayakan sendiri oleh pihak pesantren. Beberapa pesantren kurang memberdayakan potensi ini, dimana usaha di dalam pesantren hanya dikelola oleh beberapa kalangan, sehingga ruang lingkupnya tidak luas dan menyeluruh ke berbagai bidang ekonomi serta keuntungan tidak bisa sepenuhnya dikatakan menyentuh kesejahteraan lembaga ataupun para penghuni di dalamnya.

Dalam realitas pendidikan ekonomi sendiri, berbagai pelatihan untuk menggali potensi ini juga kurang didapatkan. Pesantren yang memiliki beberapa guru berlatarbelakang pendidikan ekonomi dan memiliki kreasi serta didukung pesantren dapat mencoba menggali berbagai potensi yang ada di pesantren. Sedangkan yang tidak banyak memiliki guru berlatarbelakang keilmuan ekonomi, pemberdayaan ekonomi di dalam pesantrennya kurang maksimal.

\section{Peran Pesantren dalam Penerapan Ekonomi Syariah}

Seiring dengan perkembangan masyarakat dan arus globalisasi, pondok pesantren dituntut untuk mengadakan perubahan-perubahan secara perlahan tanpa menanggalkan ciri khasnya sebagai lembaga pendidikan agama (Syarbani 2012). Pesantren sebagai lembaga pendidikan Islam memiliki potensi untuk ikut serta memberdayakan ekonomi syariah karena memiliki modal dasar yang mumpuni dalam peran pemberdayaan ekonomi syariah, baik itu penerapan maupun pengkajian hukum maupun lainnya.

Dilihat dari potensi yang ada, pesantren memiliki modal besar dalam penerapan Ekonomi Syariah di berbagai lini, baik itu pada lembaga maupun SDM yang ada di dalamnya. Hal ini disebabkan adanya kemandirian yang dijalankan pesantren sudah teruji dalam memenuhi berbagai kebutuhan para santrinya sehari-hari. Pendidikan Islami yang diterapkannya mampu menunjang penyebaran pemahaman yang baik tentang urgensi ekonomi Islam di masa modren dan berbagai akad ekonomi syariah dapat diterapkan 
pesantren dalam menjalankan roda organisasinya, baik dalam bentuk internal maupun eksternal. Di samping itu, sistem pengelolaan dan laporan anggaran dan akuntabilitas merupakan suatu keniscayaan di dalam pesantren, agar roda kehidupan yang berjalan selama 24 jam sehari di dalam pesantren dapat berjalan dengan baik dan maksimal.

Mengenai SDM yang ada di dalamnya, potensi ini juga dapat dilihat dengan adanya pengetahuan awal yang memadai tentang syariah, karena memang lembaga ini melakukan transformasi berbagai inti ajaran Islam, mulai dari Tauhid, Fikih dan Ushulnya, Bahasa Arab, Tarikh dan berbagai dasar ilmu keislaman lainnya yang sangat dibutuhkan dalam pemberdayaan potensi ekonomi syariah di dalamnya. Berikut beberapa peran yang bisa diterapkan untuk menggalakkan ekonomi syariah di dalam pesantren.

\section{Pendidikan Prinsip Ekonomi Syariah}

Sebagai lembaga pendidikan, pesantren sangat cocok mendidik dan mengajarkan berbagai prinsip ekonomi syariah yang mencakup Maysir, Gharar, Riba, Haram, Kezhaliman. Mata pelajaran seperti Tafsir, Hadis, Fiqih, Mahfuzhat (pepatah Arab) dan lainnya dapat dijadikan media dalam mendidik dan memperdalam hal-hal yang terkait prinsip ekonomi syariah. Penjabaran tentang maysir (judi), gharar (tipuan), perbuatan ribawi, berbagai objek yang diharamkan serta kezaliman sangat dapat ditekankan dalam berbagai mata pelajaran tersebut, sehingga para santri dapat mengenal secara mendalam kelima prinsip ekonomi syariah ini sebelum mereka nantinya berkecimpung di dalam dunia luar pasca pendidikan formal di pesantren.

Pendidikan lebih luas daripada pengajaran. Pengajaran termasuk di dalam pendidikan, namun tidak sebaliknya. Di dalam pesantren ilmu-ilmu yang telah disampaikan dapat langsung diterapkan langsung dalam kehidupan sehari-hari. Materi tentang shalat tahajjud misalnya, bukan hanya diajarkan di dalam pesantren namun juga diterapkan dalam kehidupan 
sehari-hari oleh para santrinya. Sering terlihat adanya motto di pesantren bahwa apa yang didengar, dilihat dan dirasakan adalah bagian dari pendidikan.

Jadi, para santri yang telah mendapatkan ilmu tentang maysir dan gharar misalnya pasti akan melakukan penerapan ilmu tersebut dengan menjauhi segala bentuk yang bersifat judi atau untung-untungan. Demikian juga halnya pelajaran tentang riba dan kezaliman, jika telah disampaikan maka dapat diterapkan dengan menjauhi perbuatan riba dan kezaliman dalam berbagai aspek dan bentuknya dalam kehidupan mereka di dalam pesantren yang kemudian akan tertanam di dalam sanubari mereka agar senantiasa menjauhi berbagai perbuatan tersebut. Sama halnya pengetahuan tentang halal-haram pasti akan diterapkan setelah mereka mengetahui dan memperdalamnya. Ilmu seperti Ushul Fiqih juga akan membantu mereka dalam mengenal dasar-dasar pengambilan hukum Islam, sehingga dapat mengukur kadar kemaslahatan yang digariskan di dalam Islam.

Dalam menjalankan kegiatan operasional pendidikan formalnya pesantren melakukannya secara mandiri. Di samping kurikulum yang telah ditetapkan perintah juga ada kurikulum lokal pesantren yang ditetapkan para pengasuh pesantren, sehingga skema pendidikan formal dan resmi pemerintah melalui Kementrian Agama atau Kementerian Pendidikan dan Kebudayaan ditambah dengan kurikulum pesantren dengan pendalaman materi keagamaan. Disini pesantren juga dapat mempertimbangkan memasukkan materi khusus tentang pendidikan ekonomi syariah di dalam kurikulum pesantren, sehingga pengenalan terhadap ekonomi syariah bisa lebih dini dilakukan. Hal ini disebabkan pengkajian mengenai ekonomi syariah sejalan dengan materi-materi agama lain yang diajarkan di pesantren, sehingga para santri dapat menghubungkan antar ilmu tersebut yang bermuara kepada pendalaman pemahaman tentang ekonomi berbasis syariah.

Economica: Jurnal Ekonomi Islam - Volume 9, Nomor 2 (2018) 
Muhammad Zuhirsyan

Pesantren juga bisa menggalakkan studi klub yang beraroma pengenalan dan pengkajian tentang ekonomi syariah yang diikuti oleh para santri dan dibimbing oleh beberapa guru yang memiliki kemampuan dalam bidang ini. Pesantren dapat memberikan kesempatan yang luas kepada para santrinya untuk mempelajari Ekonomi Syariah melalui Studi Club yang diikuti para santri yang dibimbing oleh beberapa orang guru yang memiliki kompetensi sesuai. Mereka dapat diperkenalkan dengan sistem ekonomi syariah sekaligus perbedaannya dengan sistem ekonomi konvensional yang mereka pelajari di dalam kegiatan pendidikan formal dalam mata pelajaran Ekonomi, Akuntansi maupun ilmu yang terkait lainnya. Apabila diberdayakan dengan baik, para peserta yang ikut dalam pengkajian ilmu Ekonomi Syariah ini semakin banyak setiap tahunnya dan mereka bisa diikutsertakan untuk mengikuti berbagai event Ekonomi Syariah di luar pesantren.

\section{Akad dan Kerjasama Ekonomi Syariah}

Di dalam kehidupan pesantren tentu tidak terlepas adanya berbagai kerjasama, baik secara internal maupun eksternal termasuk akad bisnis. Akad-akad bisnis yang berbasis syariah dapat diterapkan di dalam pesantren khususnya pada koperasi pesantren yang ada di dalamnya maupun pada pemasok barang ke dalam pesantren. Akad wakalah misalnya dapat digunakan bagi para pemasok barang ke pesantren. Sistem titip jual atau konsinyasi secara syariah juga dapat diterapkan bagi para pemasok barang kebutuhan santri di dalam pesantren yang bisa dikategorikan dalam akad samsarah (perantaraan jual beli) yang juga telah diperbolehkan dalam Syariah Islam. Akad Samsarah (brokerage) sangat mungkin dilakukan di dalam pesantren karena banyak kebutuhan santri di dalam pesantren yang dipenuhi dari luar, seperti jajajan/gorengan, pakaian maupun lainnya.

Seyogyanya pesantren memiliki lembaga koperasi yang bertujuan untuk memenuhi berbagai kebutuhan santri maupun guru pengasuh yang hidup di 
dalamnya. Akad-akad seperti Mudharabah, Murabahah dan lainnya dapat diterapkan. Contohnya, bagi para guru pengasuh yang memiliki tambahan modal bagi usahanya maka dia bisa melakukan akad bisnis kepada lembaga koperasi pesantren. Karena tidak bisa dipungkiri banyak juga guru yang memiliki kemampuan yang memadai untuk melakukan bisnis baik ke dalam pesantren ataupun ke luar pesantren. Para guru yang membutuhkan dana untuk melanjutkan kuliah juga dapat memenuhi kebutuhan tersebut melalui koperasi pesantren dengan menggunakan akad bisnis berbasis syariah seperti qardh maupun lainnya.

Para santri yang hidup di dalam pesantren selama 24 jam terkadang memiliki uang jajan yang diberikan orang tuanya yang datang secara berkala, baik itu sepekan atau sebulan sekali disebabkan asal daerah yang jauh dari lokasi pesantren. Tentunya dana tersebut dapat disimpan di tempat yang aman guna menghindari terjadinya hal-hal yang tidak diinginkan. Pesantren dapat memanfaatkan hal ini dengan membangun bank mini untuk menjaga dana-dana tersebut yang jika diakumulasikan berjumlah sangat banyak melalui akad syariah.

Contohnya dengan mendirikan BMT (Baitul Mal Wa al-Tamwil) di dalam pesantren merupakan solusi bagi penyimpanan dana-dana ini. BMT ini bisa ditempatkan sebagai anak usaha Koperasi Pesantren yang disamping bertujuan menjaga dana-dana tabungan pribadi para santri juga bisa digunakan untuk penyimpanan dana pesantren. Dalam menjalankan operasional kegiatannya, BMT tentu menerapkan berbagai akad bisnis yang berbasis syariah. Seiiring dengan perkembangan pesantren, BMT ini juga akan besar dengan mengaplikasikan berbagai akad syariah di dalamnya seperti Mudharabah, Murabahah, Wadi'ah dan lainnya.

Dengan bekerja sama dengan Perbankan Syariah, BMT juga dapat mengembangkan sayapnya menuju BMT yang mandiri di dalam Pesantren, guna membantu kebutuhan masyarakat pesantren maupun masyarakat luar. Dana-dana pesantren juga bisa dititipkan di perbankan syariah melalui BMT 
sehingga dapat menjadi tambahan modal bagi Perbankan Syariah dalam menjalankan operasional kegiatannya. BMT ini yang belum banyak ditemukan di berbagai pesantren, padahal potensi untuk mendirikan dan mengembangkannya sangat besar di dalam pesantren.

Termasuk pembiayaan para pengurus pesantren dalam kegiatan perjalanan dinas perlu untuk menggunakan akad yang berbasis syariah (baca: ju'alah atau ijarah). Hal ini penting mengingat kegiatan ini rentan melahirkan kecurangan (al-Gisy) yang tentu tidak sesuai dengan ajaran Islam. Selayaknya pada hal seperti ini dapat dilakukan pengkajian mendalam untuk kemudian bisa diterapkan oleh pihak pesantren.

Pesantren merupakan salah satu lembaga yang dikenal dengan sistem pengkaderannya guna melanjutkan estafet kepemimpinan pesantren di masa depan. Di samping itu, tidak jarang pesantren menugaskan seorang guru atau lebih untuk memenuhi undangan pihak lain atau penugasan kepada beberapa orang guru untuk mengembangkan diri di lembaga luar pesantren.

Dalam hal ini pesantren juga dapat menerapkan akad ijarah atau ju'alah guna menghindari penyimpangan yang terjadi di lapangan selama pelaksanaan penugasan. Dengan menggunakan akad ijarah, maka guru yang ditugaskan pesantren menggunakan dana penugasan sesuai masa waktu yang ditetapkan. Jika ada kelebihan, dimana masa penugasan bisa dipercepat dari waktu yang dijadwalkan, maka petugas pesantren tersebut dapat mengembalikan dana yang telah diberikan pihak pesantren.

Namun juga bisa menerapkan akad ju'alah dimana yang menjadi target adalah prestasi yang diraih si petugas tersebut. Jika waktu yang dijadwalkan 4 hari misalnya, namun si petugas tersebut dapat memenuhi target dalam jangka waktu 2-3 hari, maka kelebihan dari dana tugas tersebut bisa dipakai untuk kebutuhannya yang lain. Apabila akad yang seperti ini dapat 
diterapkan pihak pesantren maka akan menjadi contoh bagi lembaga lain baik yang berbentuk lembaga pesantren maupun lembaga lainnya.

Untuk memenuhi kebutuhan sehari-hari, tidak jarang para guru atau pengasuh di pesantren yang membutuhkan dana di pertengahan bulan. Mereka ini kemudian melakukan kasbon dari bendaraha yang kemudian nantinya pada bulan berikutnya dipotong dari honor bulanan yang didapat pada bulan selanjutnya. Untuk ini, pesantren seyogyanya bisa mempersiapkan kontrak khusus dalam bentuk qardh.

Lebih jauh lagi, penggunaan E-Money di masa sekarang ini sudah menjadi suatu keniscayaan, mengingat berbagai bidang bisnis di Indonesia sekarang menggunakan uang elektronik dalam transaksinya. Dengan hadirnya fatwa Dewan Syariah Nasional Majelis Ulama Indonesia (DSN-MUI) No. 116/DSN-MUI/IX/2017 tentang Uang Elektronik Syariah dapat dijadikan payung hukum pemberlakuan E-Money Syariah. Perbankan Syariah bisa mengambil kesempatan ini dengan bekerjasama dengan pihak pesantren untuk dapat menerapkan E-Money yang berbasis syariah.

Dengan demikian, wali santri yang berdomisili jauh dari pesantren dapat dipermudah dalam pengiriman dana pendidikan anaknya melalui perbankan syariah. Sistem transaksi jual-beli di dalam pesantren juga akan menjadi mudah mengingat dengan E-Money ini akan memangkas durasi antrian dalam kegiatan bisnis di internal pesantren khususnya bagi pesantren yang memiliki jumlah santri yang sangat banyak dan juga menjadi tempat penyimpanan dana siap pakai yang aman bagi santri.

\section{Akuntansi Pesantren Berbasis Syariah}

Prinsip-prinsip dasar akuntansi syariah secara umum telah dijelaskan dalam QS. Al Baqarah ayat 282, dimana Mauludi (2014) menjelaskan sebagai berikut: 
1) Prinsip Pertanggungjawaban Implikasi dalam bisnis dan akuntansi adalah bahwa individu yang terlibat dalam praktik bisnis seogyanya selalu melakukan pertanggungjawaban apa yang telah diamanatkan dan diperbuat kepada pihak-pihak yang terkait dan biasanya dalam bentuk laporan akuntansi.

2) Prinsip Keadilan Kata keadilan dalam konteks aplikasi akuntansi mengandung dua pengertian, yaitu: Pertama, adalah berkaitan dengan praktik moral, yang merupakan faktor yang sangat dominan. Kedua, kata bersifat lebih fundamental (dan tetap berpijak pada nilai-nilai etika/syariah dan moral).

3) Prinsip Kebenaran Prinsip kebenaran ini sebenarnya tidak dapat dilepaskan dengan prinsip keadilan. Kebenaran di dalam Alquran tidak diperbolehkan untuk dicampuradukkan dengan kebathilan. Alquran telah menggariskan, bahwa ukuran, alat atau instrument untuk menetapkan kebenaran tidaklah didasarkan pada nafsu

Dari penjelasan diatas tepatlah dikatatakan bahwa landasan syariah menekankan pada akuntansi. Pada ayat ini secara jelas mengemukakan fungsi-fungsi pencatatan, dasar dan manfaatnya. Untuk menunjang praktekpraktek akuntabilitas sebagai mana diamanatkan QS. Al Baqarah 282, sudah semestinya pesantren sebagai entitas syariah terkait pengelolaan ekonomi syariah melaksanakan praktek pembukuan yang handal dan akurat dimana laporan tersebut dapat dipertangungjwabakan serta diperbandingkan dengan laporan sebelumnya.

Penyusunan laporan keuangan pada pesantran merupakan bentuk transparansi dan akuntabilitas pengelolaan pesantren pada pemilik dan umat. Terkait laporan keuangan yang disusun oleh entitas syariah sesuai IAI (2016) PSAK No. 101 terdiri dari laporan posisi keuangan, laporan laba rugi, laporan perubahan ekuitas, laporan arus kas, laporan sumber dan 
penggunaan dana zakat, laporan sumber dan penggunaan dana kebajikan, catatan atas laporan keuangan.

Laporan keuangan merupakan sebuah laporan yang berisi informasi bagi pihak internal dan eksternal yang akan digunakan sebagai dasar pengambilan suatu keputusan ekonomi. Tentunya tujuan laporan keuangan ini dapat tercapai, jika laporan keuangan mengungkapkan informasi mengenai entitas syariah yang meliputi: asset, kewajiban, dana syirkah temporer, ekuitas, pendapatan dan beban termasuk keuntungan dan kerugian, arus kas, dana zakat, dan dana kebajikan.

Seluruh informasi tersebut serta informasi-informasi lainnya yang diungkapkan pada catatan atas laporan keuangan akan sangat membantu pengguna laporan dalam mengelola aset serta memperkirakan arus kas pada masa yang akan datang bagi kepentingan pesantren.

Bila dilihat dari praktik akuntansi yang sesuai standar jelas bahwa jika entitas syariah (pesantren) menerapkannya dengan baik maka akan tercipta tata kelola keuangan yang transparan dan akuntabel. Namun sayangnya beberapa penelitian mengungkapkan bahwa banyak entitas syariah tidak atau menjalankan hanya sebagian praktek akuntansi syariah, bahkan ada yang beranggapan bahwa pengelolaan organisasi syariah cukuplah dengan akad "percaya dan ikhlas" sehingga aspek-aspek transparansi dan akuntabilitas terabaikan.

Pelaksanaan praktik-praktik pengelolaan keuangan hanya berdasarkan kepercayaan bahwa dana sudah berada di jalan Allah dan tidak mungkin dilakukan penyelewengan. Sebagaimana yang dikemukan oleh Luayyi (2014) bahwa pada pondok pesantren masih kental dengan unsur amanah yang penuh ikhlas, sehingga segala sesuatunya tidak selalu dilakukan pencatatan melainkan atas dasar kepercayaan. Temuan ini tentunya sangat penuh resiko, selain manusia adalah tempatnya lupa dan lalai, namun kondisi seperti ini bisa menimbulkan godaan untuk melakukan kecurangan 
Muhammad Zuhirsyan

karena rendahnya kontrol atau pengawasan dari sisi tidak adanya pencatatan.

Hal lain mengapa praktek akuntansi tidak diterapkan pada pesantren salah satunya adalah minimnya SDM yang mengerti dan menguasai praktekpraktek akuntansi syariah.

Penerapan akuntansi syariah sangat layak dilakukan di dalam pesantren, karena juga bagian dari penerapan agama. Kelalaian atau kesalahan administrasi keuangan bisa diminimalisir, sehingga selain pertanggungjawaban kepada Allah pada kegiatan pesantren, hal yang sama juga bisa diterapkan di dunia (baca: pesantren). Seorang mukmin dituntut untuk melaksanakan perintah kepada Allah (pengembangan agama/pesantren) di waktu yang sama dia juga melaporkan pertanggungjawaban kegiatan keuangan dari pengelolaan keuangan pesantren, sehingga bisa meminimalisir kesalahan atau penyalahgunaan kekuasaan dalam bidang keuangan pesantren. Penerapan akuntansi syariah dalam pesantren juga dapat dilakukan sebagai bentuk upaya membantu percepatan pembangunan nasional. Dimana pembangunan ekonomi mikro dan makro dapat dijalankan melalui bidang usaha lembaga pendidikan, termasuk lembaga pendidikan pesantren.

Mata pelajaran akuntansi yang merupakan kajian ilmu abstraksi yang diajarkan berdasarkan kurikulum SKB 3 Menteri tentunya tidak mencakup akuntansi berbasis syariah. Untuk itu, perlu juga untuk mendirikan kelompok-kelompok belajar yang memperkenalkan dan mengajarkan akuntansi syariah, karena kehidupan pesantren biasanya dijalankan selama 24 jam, sehingga banyak waktu yang bisa digunakan untuk mendalami ini bersama guru di dalam yang memiliki kompentensi yang sesuai ataupun merekrut guru dari luar kembali untuk menjadi pembimbing dalam bidang akuntansi syariah. 
Membidik Potensi Ekonomi Syariah di...

\section{Penginapan Syariah, Kuliner dan Wisata Halal}

Peluang pemberdayaan ekonomi syariah lainnya yang dapat diterapkan oleh pesantren adalah penginapan yang berbasis syariah. Awalnya penginapan ini ditujukan untuk menampung para wali santri menginap di pesantren disebabkan domisilinya yang jauh dari pesantren, kemudian bisa mejadikan suatu penginapan yang dalam menjalankan operasionalnya bersandar dengan sistem syariah.

Kewajiban memperlihatkan identitas sebagai pasangan mahram misalnya dapat diterapkan guna menghindari berbagai hal yang tidak diinginkan. Sistem penyewaan juga dapat dilakukan dengan menggunakan akad bisnis syariah (baca: Ijarah), sehingga para tamu pada akhirnya diperkenalkan juga dengan akad syariah.

Dengan adanya tempat penginapan ini pesantren dapat membantu para wali santri yang menitipkan anaknya didalam pesantren, sehingga tidak menggunakan hotel atau penginapan lain yang belum diketahui kenyamanannya.

Seiiring dengan perjalanan waktu, pesantren dapat membesarkan penginapan ini menjadi hotel syariah yang juga melayani para tamu dari luar keluarga besar pesantren dengan tentunya menerapkan sistem syariah dalam menjalankan operasional kegiatannya, sehingga pesantren bisa memberikan kontribusi dalam perkembangan sistem ekonomi syariah ke depannya.

Disamping itu, pembuatan produk makanan halal yang awalnya mungkin ditujukan untuk konsumsi tambahan santri/wati di dalam pesantren bisa dikembangkan dan dipasarkan di luar pesantren dengan memberikan label halal (bekerjasama dengan MUI setempat), sehingga membuat konsumen lain bisa merasakan kenyamanan saat mengkonsumsi makanan/kuliner tersebut. 
Hal ini dipandang sangat perlu disebabkan di masa sekarang ini, banyak produsen makanan yang menjual produk yang belum jelas keamanan dan kehalalalannya. Jika produk tersebut lahir dari pesantren maka ini dapat meminimalisir keraguan konsumen dalam membeli makanan yang diproduksi dari dalam pesantren. Demikian juga dengan mendirikan unit usaha cattering yang membantu berbagai pihak menyediakan konsumsi di berbagai acara. Usaha-usaha seperti ini berpotensi menjadi "ladang" bagi pesantren untuk menambah pundi-pundi dana guna pengembangan pesantren di masa depan.

Jika ini diurus dengan baik, bukan tidak mungkin kuliner yang diproduksi dari dalam pesantren yang terjaga kehalalannya dapat menjadi kuliner yang terkenal yang banyak akan diminati para konsumen dan pada akhirnya nantinya bisa kerap dijadikan buah tangan oleh para wisatawan yang datang dari luar daerah. Tentunya dalam merealisasikan hal diatas pesantren dipastikan mesti memiliki modal yang memadai, baik itu modal materi, ide-pikiran, serta sistem produksi dan pemasaran yang tentunya berbasis syariah. Dengan keinginan yang kuat, berbagai hal diatas bisa diwujudkan disertai niat ikhlas dan kerjasama yang baik.

Pesantren juga bisa menawarkan wisata halal kepada masyarakat melalui pendirian travel yang menyediakan jasa wisata halal. Ini juga dapat menjadi angin segar bagi para wisatawan yang menginginkan perjalanan wisatanya mendapatkan rasa aman dan halalan thayyiban. Mengingat di masa sekarang banyak travel yang belum bisa menjamin wisata halal bagi konsumen. Dimana dengan nama pesantren yang sudah dikenal sebagai lembaga Islam, travel yang dibina pesantren akan mendapatkan kepercayaan oleh masyarakat, khususnya mereka yang menginginkan jaminan wisata halal dalam perjalanan mereka. 


\section{Peran Pesantren dalam Pengembangan Ekonomi Syariah}

Selain sebagai lembaga yang bisa untuk menerapkan sistem ekonomi syariah, pesantren juga dapat dijadikan sebagai lembaga pengembangan ekonomi syariah, mengingat potensi SDM yang ada di dalam pesantren layak untuk melakukan tugas ini. Selain tauhid dan akhlak, di dalam pesantren juga diajarkan pendidikan syariah dalam berbagai lini yang bisa diarahkan dan diperluas sayapnya menjadi lembaga pengembangan ekonomi syariah. Ilmuilmu seperti Hadis, Fiqih dan Ushul Fiqih yang menjadi dasar ekonomi syariah diajarkan di dalam pesantren, sehingga pengembangan ilmu-ilmu ini bisa menarik pengembangan terhadap ilmu ekonomi syariah. Beberapa pengembangan ekonomi syariah yang bisa digalakkan di dunia pesantren adalah sebagai berikut:

\section{Pesantren Sebagai Laboratorium Ekonomi Syariah}

Selain sebagai lembaga pendidikan dan penyebaran agama, pesantren juga bisa menjadi laboraturium kemasyarakatan, termasuk ekonomi syariah. Adapun yang dimaksud laboratorium disini adalah bahwa di dalam pesantren bisa bisa dikaji, diuji dan diterapkan sistem ekonomi syariah. Berbagai aspek ekonomi bisa dikaji perspektif hukum untuk kemudian diterapkan sebagai upaya membangun berbagai bentuk ekonomi kreatif umat.

Tidak berlebihan juga kalau disebut bahwa pesantren adalah miniatur kehidupan bermasyarakat, karena kehidupan di dalam alam pesantren merupakan pendidikan dan pengamalan terhadap nilai-nilai agama yang berisikan berbagai tantangan dan solusi pemecahaannya. Sistem kepemimpinan yang ada di dalam pesantren tampak berfungsi sebagai pemimpin yang sekaligus melakukan pengayoman, pembinaan yang sekaligus menjalankan fungsi kontrol dan pengawasan terhadap berbagai kegiatan dan peristiwa yang terjadi di dalam pesantren. 
Pesantren bisa diibaratkan miniatur sebuah negara, dimana kyai adalah presidennya. Sang presiden bisa menginstruksikan penerapan dan sekaligus pengkajian berbagai bentuk akad yang berbasis syariah maupun sistem ekonomi syariah di dalam pesantren guna memenuhi berbagai kebutuhan yang mesti dipenuhi di dalam pesantren. Meskipun ada juga pesantren yang menjalankan kepemimpinan dalam bentuk kolektif kolegial tidak berbeda dengan kepemimpinan yang dipaparkan sebelumnya.

Pemimpin (baca: di pesantren) bisa menginstruksikan unit-unit usaha yang berjalan di dalam pesantren menyesuaikan dengan kegiatan bisnis perspektif syariah, dengan menjunjung tinggi prinsip ekonomi Islam dan disertai upaya pengembangan hukum ekonomi syariah sebagai payungnya. Berbagai akad atau penerapan ekonomi syariah yang lain jauh dari prinsip riba, gharar, maysir, objek haram dan juga kezaliman, baik dari penganggaran di dalam pesantren sampai pelaporan bisa dilaksanakan dengan berbasis ekonomi syariah. Berbagai isu ekonomi syariah lain juga bisa diterapkan sekaligus dikaji aplikasi pelaksanaannya secara berkesinambungan, mengingat sumber daya insani yang ada di dalam pesantren memumpuni dalam bidang ini.

Sampai saat ini kemandirian pesantren merupakan suatu hal yang kerap diapresiasi berbagai pihak. Dengan pendanaan mayoritas dari santri, pesantren dapat mengembangkan berbagai sistem ekonomi syariah guna menghidupkan dan membesarkan pesantren. Di samping itu, pesantren juga dapat menjadi pusat pengkajian berbagai akad bisnis syariah penelitian dan pengkajian berbagai akad ekonomi syariah yang belum tergali melalui kerjasama dengan berbagai pihak terkait. Sumber daya Insani yang dimiliki pesantren dapat diberdayakan untuk melakukan misi mulia ini, karena mayoritas penduduk pesantren merupakan orang-orang yang sudah mengenal dan mendalami ilmu agama yang hanya membutuhkan sedikit "sentuhan" untuk bisa menjadikan mereka sebagai para duta dan pengkaji akad bisnis syariah. 
Membidik Potensi Ekonomi Syariah di...

\section{Forum Bisnis Pesantren}

Forum ini dilakukan dengan dipandu beberapa staff pengajar dan para pengelola yang bisa ikut serta masuk ke dalam forum dengan topik seputar pendidikan dan bisnis pesantren tentunya. Dengan adanya forum ini diharapkan para pengelola dapat bertukar informasi dan berdiskusi membahas pengembangan pesantren.

Sepertinya bentuk model ini belum berjalan dengan maksimal di dunia pesantren di Sumut. Banyak pesantren yang berjalan sendiri tanpa ada kerjasama dengan pesantren lainnya. Kalaupun ada forum-forum ini, namun belum menyentuh ke permasalahan ekonomi syariah. Jika menginginkan Islamic Economy bisa menandingi ekonomi konvensional, maka kaum muslimin seyogyanya bekerjasama antara satu dengan lainnya. Pesantren didorong untuk melakukan gebrakan dan kerja sama ekonomi syariah antar pesantren disamping bidang pendidikan, hal ini sebagai wujud nyata pemberdayaan ekonomi yang lebih terbuka dan saling berbagai informasi mengenai pengembangan lembaga pendidikan pesantren.

Para calon santri yang tidak dapat ditampung di suatu pesantren misalnya, dapat dialihkan ke pesantren lain yang memiliki model pendidikan yang senada yang tentunya akan terealisasi melalui adanya forum bisnis antar pesantren ini. Contoh lainnya, produk-produk yang dihasilkan di suatu pesantren bisa dipasarkan di pesantren lainnya, sehingga produksi pesantren akan semakin berkembang yang dibantu oleh konsumen dari pesantren lainnya. Demikian juga halnya kegiatan-kegiatan kerjasama bisnis lainnya yang lebih besar akan mudah terwujud dengan adanya forum ini yang dilakukan secara maksimal oleh beberapa pesantren, sehingga kemandirian pesantren akan semakin baik ke depan. Informasi dan solusi dari problematika yang ditemukan di alam pesantren juga akan semakin mudah tersampaikan dan tersebar. 
Muhammad Zuhirsyan

Dengan adanya forum bisnis ini, pesantren yang relatif lebih muda akan mengambil berbagai ilmu pelajaran dalam bidang bisnis khususnya dari pesantren-pesantren yang lebih lama dan lebih besar. Berbagai kebutuhan santri dapat saling disharing distribusinya. Bagi beberapa pesantren yang memiliki model yang senada, distribusi buku pelajaran akan lebih mudah diwujudkan melalui adanya forum bisnis antar pesantren ini. Pesantren yang lebih tua atau yang lebih besar bisa saja membuka Perguruan Tinggi, sehingga para alumni dari pesantren yang relatif lebih muda bisa saja masuk ke dalam Perguran Tinggi tersebut. Melalui kerjasama antar pesantren, bisnis halal mart yang mengedepankan bisnis halalan thoyyiba yang mulai populer di masa sekarang ini bisa dikembangkan dengan maksimal guna memenuhi kebutuhan konsumsi masyarakat dalam bidang produk herbal, baik itu produk makanan, kecantikan, obat-obatan maupun produk-produk lainnya.

\section{Menjadikan Pesantren Sebagai Islamic Economy Centre}

Para santri yang mengecap ilmu pendidikan agama di pesantren tentu memiliki ilmu agama yang sangat memumpuni. Para santri yang telah menyelesaikan pendidikannya ditambah para santri kelas akhir yang sudah lebih memumpuni bidang keilmuan agamanya bisa membuat suatu lembaga pusat ekonomi yang membahas berbagai penerapan dan pengembangan ekonomi Islam, yang kemudian dapat dibukukan dan dipublikasikan di dunia luar pesantren.

Alangkah lebih baik, pesantren yang sudah besar tingkat kemandiriannya bisa menambah jenjang pendidikan yang lebih tinggi seperti perguruan tinggi yang membuka program studi ekonomi, keuangan ataupun perbankan syariah guna mendukung program membumikan ekonomi syariah di Indonesia. Dengan adanya perguruan tinggi ini bisa dijadikan Islamic Economi Centre yang melayani berbagai bentuk penerapan dan pengembangan ekonomi Islam baik di dalam internal pesantren maupun 
eksternal dengan bekerjasama dengan lembaga terkait. Lembaga pusat ekonomi syariah ini dapat bekerjasama dengan perguruan tinggi lain yang senada beserta dunia perbankan syariah maupun lembaga terkait lainnya untuk melebarkan sayap ekonomi Islam baik dalam bidang penelitian maupun pengabdian kepada masyarakat.

Selain sebagai pusat pengkajian ilmu keislaman, pesantren juga bisa menjadi lembaga penyimpanan dan penyaluran dana umat yang didapat dari kegiatan zakat, infak dan sedekah yang diperoleh dari masyarakat, wali santri maupun dari para guru atau pengelola pesantren itu sendiri. Karena tidak sedikit masyarakat muslim (termasuk para wali santri) yang berpotensi dengan sukarela menyisihkan hartanya untuk kepentingan jalan Allah, dan kemudian mencari lembaga independen yang terpercaya untuk mengumpulkan dan menyalurkan dana-dana tersebut. Dengan adanya trust dari masyarakat, pesantren dapat menjadi penghimpun dan pengelola dana tersebut untuk kemudian disalurkan ke tempat-tempat yang sudah ditetapkan ajaran syariah.

Menjadikan pesantren sebagai Islamic Economy Centre bukan mustahil, apabila para pengambil kebijakan di dalamnya dapat berusaha semaksimal mungkin mewujudkan pemberdayaan ekonomi syariah melalui kerjasama dengan berbagai pihak, baik itu dengan lembaga pesantren lainnya maupun lembaga lain yang berkompeten.

\section{Menjadi Inspirator Pengembangan Ekonomi Berbasis Syariah}

Jika berbagai bentuk pengembangan ekonomi syariah sebagaimana yang telah disebutkan sebelumnya diatas telah berjalan dengan baik, maka pesantren dengan segala bentuk kemandiriannya bisa menjadi inspirator pengembangan ekonomi berbasis syariah. Dimulai dari para alumni pesantren tersebut yang bisa menerapkan berbagai potensi usaha bisnis berbasis syariah sebagai bentuk pengamalan dari ilmu ekonomi syariah yang telah diajarkan dan diterapkan di pesantren. Para alumni yang biasanya 
militan dan sangat kompak bisa mendirikan berbagai usaha dengan menjalankan praktik ekonomi syariah, guna memperkuat ekonomi umat.

Kemadirian pesantren dalam mengelola pemberdayaan ekonomi syariahnya bisa menjadi inspirasi bagi berbagai lembaga lain untuk menerapkan hal yang sama. Misalnya berbagai lembaga pendidikan lainnya seperti sekolah, madrasah maupun pendidikan tinggi baik yang bersifat boarding school maupun yang tidak, yang secara praktis memiliki banyak kesamaan dengan sistem pesantren bisa saja termotivasi untuk menerapkan potensi pemberdayaan ekonomi syariah yang telah dipraktikkan oleh pesantren.

Contoh lain adalah dalam pengembangan instrumen ekonomi Syariah berupa wakaf. Karena wakaf termasuk instrumen ekonomi pembangunan islam yang memiliki pengaruh cukup baik untuk kemaslahatan umat (Fuadi 2018). Pondok Modern Darussalam Gontor telah lama mempraktikkan wakaf produktif hingga mampu mengembangan pondok pesantren tersebut semakin pesat (Budiharjo 2011). Bahkan universitas islam terkemuka seperti Al-Azhar University juga menerapkan wakaf sebagai sumber pendanaan institusi, baik untuk kegiatan belajar mengajar maupun untuk operasional (Fuadi 2013).

Bahkan, pemberdayaan potensi ekonomi syariah ini juga bisa menjadi inspirasi bagi berbagai lembaga selain pendidikan. Perusahan yang berbadan hukum selain yayasan pendidikan juga bisa terinspirasi dengan pengelolaan dan pemberdayaan ekonomi syariah dalam mengoperasikan berbagai sendi perekonomiannya seperti penerapan akad bisnis syariah di internal perusahaan maupun eksternal, sehingga prinsip keadilan dan anti-kezaliman dapat dirasakan oleh berbagai pihak. 


\section{Simpulan}

Berbagai potensi sumber daya yang ada di dalam pesantren dapat diberdayakan sebagai fasilitas dalam penerapan dan pengembangan ekonomi Islam sebagai solusi dari sikap penghindaran diri dari prilaku ribawi. Pemberdayaan ekonomi Islam ini dalam bentuk penerapan di dalam pondok pesantren dapat diklasifikasi dalam beberapa hal, di antaranya pendidikan prinsip ekonomi syariah, akad dan kerjasama ekonomi syariah, akuntansi Pesantren serta penginapan syariah dan Kuliner Halal.

Sementara dalam bentuk pengembangan ekonomi syariah, pesantren sebagai lembaga yang dikenal dengan kemandiriannya dapat melakukan pemberdayaan pada beberapa hal berikut seperti: menjadikan pesantren sebagai laboratorium ekonomi syariah, forum bisnis syariah, Islamic Ekonomy Centre serta inspirator pengembangan ekonomi berbasis syariah.

Harapannya ke depan, pesantren sebagai lembaga pendidikan Islam dapat bekerjasama dengan berbagai pihak untuk mewujudkan kemandirian ekonomi dengan memberdayakan potensi penerapan dan pengembangan ekonomi Syariah .

Dari hasil kesimpulan, maka disarankan :

1. Pesantren perlu membumikan ekonomi syariah semaksimal mungkin untuk menghidupkan sistem muamlah Islam di dalam lingkungan pesantren.

2. Meningkatkan pendapatan dalam kemandirian pesantren untuk melakukan sosialisasi dan juga komponen lain dalam bidang usaha meningkatkan kemampuan bersaing dengan lembaga lainnya.

3. Memberdayakan segala potensi yang ada termasuk teknologi informasi melalui website atau media sosial dalam mempromosikan kondisi terkini pesantren dalam perspektif ekonomi syariah yang ditawarkan kepada masyarakat. 
Muhammad Zuhirsyan

4. Menjunjung tinggi nilai transparansi dalam pengelolaan pesantren agar menjadi contoh bagi lembaga lainnya, salah satunya dengan melakukan penerapan akad dan juga akuntansi berbasis syariah.

\section{Daftar Pustaka}

AC, Ali Mauludi. 2014. "AKUNTANSI SYARIAH; Pendekatan Normatif, Historis Dan Aplikatif." IQTISHADIA: Jurnal Ekonomi \& Perbankan Syariah 1 (1): 59. https://doi.org/10.19105/iqtishadia.v1i1.366.

Budiharjo, Anas. 2011. "Pengelolaan Wakaf Produktif Di Pondok Modern Darussalam Gontor Ponorogo.” UIN Sunan Kalijaga Yogyakarta.

Daulay, Haidar Putra. 2014. Sejarah Pertumbuhan Dan Pembaruan Pendidikan Islam Di Indonesia. Jakarta: Kencana Prenada Media Group.

Fatah, Rohadi Abdul, M. Tata Taufik, and Abdul Mukti Bisri. 2005. Rekonstruksi Pesantren Masa Depan. Jakarta: PT. Listafariska Putra.

Fuadi, Nasrul Fahmi Zaki. 2013. “Intensi Nasabah Bank Syariah Untuk Berwakaf Uang Di Badan Wakaf Indonesia (BWI): Studi Kasus Pada Bank Syariah Mandiri Jakarta Pusat." Universitas Indonesia.

___. 2018. "Wakaf Sebagai Instrumen Ekonomi Pembangunan Islam." Economica: Jurnal Ekonomi Islam 9 (1): 151. https://doi.org/10.21580/economica.2018.9.1.2711.

Haedari, Amin. 2006. Panorama Pesantren Dalam Cakrawala Modren. Jakarta: Diva Pustaka.

Hafidhoh, Noor. 2016. "Pendidikan Islam Di Pesantren Antara Tradisi Dan Tuntutan Perubahan." Muaddib : Studi Kependidikan Dan Keislaman 6 (1). https://doi.org/10.24269/muaddib.v6i1.161.

Hasan, Muhammad Tholhah. 2004. Agama Moderat, Pesantren Dan Terorisme. Jakarta: PT. Listafariska Putra.

IAI, Ikatan Akuntan Indonesia. 2016. Standar Akuntansi Keuangan. Revisi 201. Jakarta: Salemba Empat.

Luayyi, Sri. 2014. Akuntansi Syariah (Aset Dan Bentuk Pelapirannya Dari Kaca Mata Pondok Pesantren). Kediri: Dimar Intermedia. 
Marlina, Marlina. 2014. "POTENSI PESANTREN DALAM PENGEMBANGAN EKONOMI SYARIAH." JURNAL HUKUM ISLAM 12 (1). https://doi.org/10.28918/jhi.v12i1.532.

Rahardjo, Dawam M. 1985. Pergulatan Dunia Pesantren: Membangun Dari Bawah. Jakarta: Perhimpunan Pengembangan Pesantren dan Masyarakat (P3M).

Syarbani, Hasyim. 2012. “Analisis Pengaruh Partisipasi Santri Komitmen Dan Kemampuan Berinovasi Terhadap Kinerja Koperasi Pondok Pesantren Di Kota Semarang." Economica: Jurnal Ekonomi Islam 2 (2). https://doi.org/10.21580/economica.2012.2.2.848.

Wibowo, Andi. 2016. "Peran Pondok Pesantren Al-Haidar Dan Pembinaan Remaja Desa Penjalin Brangsong Kendal," June.

Zuhriy, M. Syaifuddien. 2011. "Budaya Pesantren Dan Pendidikan Karakter Pada Pondok Pesantren Salaf." Walisongo: Jurnal Penelitian Sosial Keagamaan 19 (2): 287-310. https://doi.org/10.21580/WS.19.2.159. 
